\title{
Opettajien täydennyskoulutuksen ongelmat korkeakoulun näkökulmasta
}

\begin{abstract}
Kari, Jouko. 1982. Opettajien täydennyskoulutuksen ongelmat korkeakoulun näkökulmasta. Aikuiskasvatus 2, 3, 92-95. - Artikkelissa käsitellään opettajien täydennyskoulutuksen organisointiin ja pedagogiseen toteuttamiseen liittyviä ongelmia. $\mathrm{Ha}$ vaintoesimerkkeinä jo toteutetusta täydennyskoulutuksesta tarkastellaan opettajankouluttajien lakisääteistä jatko-opiskelua ja peruskoulun SIVA-koulutusta. Erityisesti painotetaan koulutustutkijain osallistumismahdollisuuksia täydennyskoulutuksen toteuttamiseen.
\end{abstract}

Opettajien täydennyskoulutus kaikilla koulujärjestelmän osa-alueilla ja aivan erityisesti yleissivistävien, ammatillisten sekä korkea-asteen koulutuksessa on muodostumassa erääksi keskeiseksi kehittämistoiminnan kohteeksi 1980-luvulla. Maamme yliopistoille ja korkeakouluille on esitetty runsaasti haasteita tämän toiminnan edelleen kehittämiseksi. Tähän ongelmaan on kiinnitetty huomiota mm. luonnoksessa korkeakoululaitoksen kehittämissuunnitelman tarkistamiseksi vv. 1983-1986 (Opetusministeriö, korkeakoulu- ja tiedeosasto 11.5 .1982 ).

Korkeakoulujen antamalla täydennyskoulutuksella tarkoitetaan kaikkea korkeakoulujen toimesta suunniteltua ja annettua lisäkoulutusta, joka ei johda tieteellisiin tai ammatillisiin jatkotutkintoihin. Uusina vivahteina tähän toimintaan ovat tulleet viime vuosina myös akateeminen työllisyyskoulutus ja avoin korkeakouluopetus.

Tehokkaimmillaan täydennyskoulutus on silloin, kun se liittyy korkeakoulussa annettuun perusopetukseen sekä asianomaisessa korkeakoulussa tehtävään tutkimukseen. Ei ole sen vuoksi ihme, että kentällä toimivien opettajien katseet toiveikkaina suuntautuvat korkeakouluihin täydennyskoulutuksen järjestelykysymyksissä. Opiskelun päällimmäisenä motiivina on luonnollisesti hankkia omassa ammatissa ja siihen kuuluvissa, ehkä muuttuneissakin tehtävissä tarpeellisia perustutkintoa korkeampia tai erikoistuneempia tietoja ja taitoja. Tietenkään ei pidä unohtaa myöskään niitä, jotka asettavat täydennyskoulutusjaksonsa tavoitteeksi yleissivistävät opinnot ja harrastukset yksilöllisten tavoitteenasettelujensa pohjalta. Myöskään korkeakoulututkin- non suorittaminen ei ole yleensä välttämätön edellytys täydennyskoulutukseen osallistumiselle.

Tässä artikkelissa tarkastellaan opettajien täydennyskoulutuskysymyksiä lähinnä organisatorisesta ja hieman myös didaktisesta näkökulmasta katsoen eräiden esimerkkitapausten pohjalta.

\section{Opettajien täydennyskoulu- tuksen järjestämisen periaat- teita}

Opettajat ovat perinteisesti olleet hyvin täydennyskoulutukseen halukkaita ammattihenkilöitä. Niinpä esimerkiksi Jyväskylä (seminaari, Kasvatusopillinen korkeakoulu ja nyttemmin Jyväskylän opisto) on jo vuodesta 1912 lähtien ollut opettajien perinteinen täydennyskoulutuspaikka erityisesti kesäisin.

Kesäyliopistoidea on sittemmin levinnyt laajalti koko maahan kaikkien korkeakoulujen vaikutusalueilla. On niin ollen varsin järkevää ja taloudellista kytkeä nykyinenkin kesäyliopistojen korkeakouluopetus (korkeakoulujen opetussuunnitelman mukainen opetus) kiinteäksi osaksi korkeakoulujen opettajille tarjoamaa täydennyskoulutusta. Näin alueellinen aloitteisuus, opettajien koulutustarpeet ja toisaalta korkeakouluissa suunniteltavat opetusohjelmat voivat ainakin osittain sopeutua toisiinsa.

Olennaisinta parannusta täydennyskoulutuksen tehokkuudessa merkinnee kuitenkin se, että tulevaisuudessa koko maan kattava täydennyskoulutusjärjestelmä toimii periaatteessa ympärivuotisesti. Täydennyskoulutuskeskuksia on alettu toden teolla perustaa pääyliopis- 
tojen yhteyteen tai ns. sivukorkeakoulupaikkakunnille. Myös alueellista koulutusvastuun jakoa on pohdittu sekä yksityisesti että valtakunnallisten työryhmien puitteissa viime vuosina (Alikoski 1977.)

Varsinaista virkakoneistoa täydennyskoulutusjärjestelmä tuskin kohtuuttomasti paisuttaa. Välttämätöntä kai kuitenkin on luoda kaikkiin korkeakouluihin täydennyskoulutuksen hallinto-, yleissuunnittelu- ja toimistotehtäviä varten pysyvä henkilöstö. Mikäli pysyviä näyttelyjä tai konsultointia sekä opetuksen demonstrointia halutaan sisällyttää käytännöllisinä ja yleisesti toivottuina sisältöinä koulutukseen, lisäävät ne jonkin verran materiaalisten resurssien tarvetta.

On suunniteltu, että täydennyskoulutuksen opettajat olisivat yleensä korkeakoulujen varsinaisia opettajia tai ulkopuolisia asiantuntijoita. Eräänä tällaisten ulkopuolisten asiantuntijain ryhmänä tulevat varmasti kysymykseen opettajien täydennyskouluttajina kasvatusalan ja erityisesti koulutuksen tutkijat. Kasvatustieteiden tutkimuslaitoksessa, joka toimii Jyväskylän yliopiston erillislaitoksena, on lähes parin vuosikymmenen ajan tehty runsaasti yleissivistävään koulutukseen ja korkea-asteen koulutukseen liittyvää tutkimusta ja kouluviranomaisten pyytämiä mm. koulun uudistustoimenpiteisiin liittyviä selvityksiä sekä syvällisempääkin kasvatustieteellistä ja oppimispsykologista tutkimusta. Myös ammatilliseen koulutukseen liittyvä tutkimustoiminta on laitoksessa käynnistynyt aikaisempaa vireämpänä 1980-luvun alussa.

Uudessa koulutusjärjestelmässä näillä tutkijoilla olisi myös kouluttajina tärkeä merkitys. Tutkimuslaitoksen taholta onkin tehty aloite, että tutkijoille tulisi varata aika ajoin mahdollisuus täydennyskoulutustehtäviin. Tutkimuslaitos voi rajoitetussa määrin toimia myös koulutuspaikkana. Tutkimuksen hyödyntämistä opettajien täydennyskoulutuksessa on tämän kirjoittaja käsitellyt aikakauskirja Kasvatuksen artikkelissa (Kari 1980).

Opettajien virkaehtosopimuksissa määriteltävä koulutus toteutetaan todennäköisimmin säännöllisesti toistuvina lyhyinä jaksoina. Yhteistyössä opettajien itsensä, virallisen kouluhallinnon, esimerkiksi lääninhallitusten, ja korkeakoulujen kanssa koulutusjaksot ja niiden sisältö voitaneen järjestää opettajistoa tyydyttäviksi.
Esimerkkejä eräiden opettajaryhmien täydennyskoulutuksen didaktisesta toteuttamisesta

Hyvin hyödylliseksi koettu - joskin meillä vielä harvinainen - esimerkki läpi opettajan virkauran kestävästä jaksottaiskoulutuksesta, jossa koulutus ja työnteko vuorottelevat tarkoituksenmukaisella tavalla, on opettajankouluttajina toimivien lehtoreiden lakisääteinen jatko-opiskelu. Tämä koulutusmuoto käynnistyi syksyllä 1974 (Sysiharju - Kari 1975, Sysiharju 1976). Seitsemän palveluvuoden väliajoin toistuvasta yhden lukukauden kestävästä täydennyskoulutuksen muodosta on säädetty opettajankoulutuslainsäädännössä 1970-luvun alkupuolella.

Tämän koulutuksen järjestelyssä on alun perin pyritty hyvin opiskelijakeskeiseen toteutukseen. Seuraavat periaatteet ovat olleet keskeisiä:

- Koulutus on ollut ajallisesti riittävän laajaa, jotta koulutettava ehtii uudistaa omia opetus- ja kasvatusmenettelyjään sekä saada myös runsaasti uusia persoonallisia virikkeitä.

- Lukukauden mittaisesta yksilöllisesti laaditusta koulutusohjelmasta vain $2-3$ viikkoa on käytetty yhteisiin seminaareihin ja kontaktiopetukseen.

- Koulutettavalta on vaadittu suppea omaan työkenttään liittyvä tutkielma.

Koulutusta ovat yleensä johtaneet opettajankoulutusyksiköiden professorit ja apulaisprofessorit yhdessä opetusministeriön edustajien kanssa.

Kentän opettajien täydennyskoulutusta tuskin voidaan yhtäkkiä käynnistää määrällisesti kovin mittavana. Koko akateemisen työvoiman avainryhmien, esimerkiksi juuri opettajien, laajan rintaman täydennyskoulutusratkaisuissa kaivataan ehkä hiukan kiinteämpiä koulutusmuotoja.

Jotkut edellä esitellyn koulutusmuodon tutkielmista, jotka on pyritty tietoisesti pitämään hyvin lähellä käytännön opetustyötä, ovat toisaalta osoittautuneet hyödyllisiksi ja virikkeitä antaviksi oppimateriaaleiksi opettajien perusja täydennyskoulutuksessa laajemminkin.

Kun kysymyksessä on jonkin koulutusmuodon mittava uudistus, herää opettajistossa voimakas täydennyskoulutustarve, joka johtuu itse uudistuksesta. Toisaalta akateemisten tutkintojen sisällön nopea vanhentuminen, am- 
mattitehtävien muutokset sekä yhteiskunnan yleinen muuttuminen lisäävät täydennyskoulutustarvetta opettajien keskuudessa, joiden tehtävä kulttuuriperinnän siirtämisessä ja uuden yhteiskunnan jäsenten kasvattamisessa on erittäin keskeinen.

Opettajien täydennyskoulutuksen toteuttaminen on erityisesti siirtymävaiheessa hyvin vaativa tehtävä, joka herättää herkästi myös koulutettavien kritiikkiä. Erään esimerkin tästä saamme, kun tarkastelemme jo historiaan jäänyttä peruskoulun siirtymävaiheen koulutusta (ns. SIVA-koulutus).

SIVA-koulutus oli opettajien virkavelvollisuuteen kuuluvaa täydennyskoulutusta, jota järjestettiin peruskoulujärjestelmään siirtyvien kuntien opettajille kolmen vuoden ajan alkaen sinä vuonna, jolloin kunta siirtyi peruskoulujärjestelmään.

Tämä esimerkki esitetään sen vuoksi, että siitä on käytettävissä systemaattisesti esitetty opetusteknologinen kritiikki (Renko - Taipale 1973), joka on muita siirtymävaiheen koulutustarpeita suunnitteleville kenties hyvin opettavainen.

Suunnitelma oli hyvin perusteellisesti laadittu. Kouluhallituksen toimesta valmistettiin kutakin koulutuspäivää varten kunnankouluttajien eli ohjaavien opettajien oppaat sekä opettajille tarkoitetut opintovihot. Kouluttajatehtävissä kunnan tasolla toimivat kuntien koulutoimenjohtajat tai opetuspäälliköt sekä yksityiskohtaisimmissa sovellutuksissa ohjaavat opettajat. Kuntatason kouluttajat oli valmennettu tehtäviinsä viisi päivää kestäneillä kursseilla, joissa puolestaan opettajina toimivat aluetason eli lääninkouluttajat. Heidät oli koulutettu tehtäväänsä viiden päivän kursseilla, joissa opettajina olivat alansa korkeinta asiantuntemusta edustavat valtakunnan kouluttajat.

Kritiikin kärki kohdistui tuolloin mm. siihen, että:

- Koulutustarpeen yksilöllisyys jäi vaille huomiota; eri tehtävissä toimineiden opettajien erilaista koulutustarvetta ei huomioitu riittävästi.

- Myöskään oppimistulosten kontrollia SIVA-koulutukseen ei liitetty. Oppimistavoitteiden puutteellisen määrittelyn takia toisaalta ketään ei voitu vapauttaa "täysin oppineena" ja toisaalta koulutuksen suuntautuminen ja vaatimustaso jäivät ilmeisesti kouluttajien varaan.

- Koulutuksen ajoituksessa eri opettajaryhmille esiintyi epätarkoituksenmukaisuutta.
Tekijät esittivät eräänä parannusehdotuksenaan koulutusjärjestelmän yksinkertaistamista mm. niin, että kolmiportainen koulutus korvattaisiin kaksiportaisella poistamalla kunnankouluttajat, jolloin lääninkouluttajat, joiden määrää vain olisi lisättävä, toimitsivat suoraan kuntien koulutuspäivillä. Edelleen tekijät esittivät ehdotuksia luentomuotoisen ja ryhmätöinä toteutettujen opetusmuotojen keskinäisistä suhteista sekä radion ja television käytöstä käyttökelpoisena etäopetuksen muotona opettajien täydennyskoulutuksessa.

\section{Arviointia nykytilanteesta}

Kuten edellä esitetyt esimerkit antavat havainnollisesti ymmärtää opettajien täydennyskoulutusongelmat ovat toisaalta organisatorisia, koulutettavien määrästä ja laadusta riippuvia sekä toisaalta didaktisia, opetustilanteisiin liittyviä ongelmia.

Mikäli nykyisten "voimassa olevien"' suunnitelmien perusteella voidaan jotakin ennakoida, muodostunee yliopistojen täydennyskoulutuskeskuksia voimakkaasti hyväksi käyttävä järjestelmä kehittämiskelpoiseksi opettajien täydennyskoulutustarpeita silmällä pitäen. Kritiikistäkin lienee jotakin opittu.

Opettajien jatkokoulutustoimikunnan mietinnön (1973:51) ilmestymisen jälkeen on tapahtunut paljon tämän ammattiryhmän täydennyskoulutuksen saralla.

Yleiset korkea-asteen täydennyskoulutuksen suuntaviivat on hahmotettu professori Martti Takalan johtaman täydennyskoulutustoimikunnan mietinnöissä jo 1970 luvun puolivälin tienoilla. Mietinnöissä kaavailtiin toteutus kolmivaiheiseksi.

1. Käynnistämisvaihe 1978-81

2. Kasvuvaihe $1982-85$

3. Kehittynyt vaihe $1986-$ (Komiteanmietintö 1975:57, 88; Lampi 1977)

Karkeasti arvioiden opettajien täydennyskoulutussuunnitelmien osalta esitetyssä aikataulussa ollaan vielä joten kuten kiinni. Koulutuksen määrällisten ehdotusten osalta varmaankin joudutaan tinkimään.

Toimikunta teki pedagogisesti myös erittäin huomionarvoisia ehdotuksia esittäessään, että pedagogiseen kehittämistyöhön varattaisiin 2,5 miljoona markkaa ja järjestelmän suunnitteluun 1 miljoona.

Toivottavasti nämä ehdotukset eivät jää mietintöjen vanhetessa pölyttymään, sillä opettajien täydennyskoulutus vaatii erityisesti alkuvaiheessaan huolellista suunnittelua ja jatkuvaa kehittelyä. 


\section{Lähteet:}

Alikoski, J. 1977. Korkeakoulujen täydennyskoulutusvastuusta. Kasvatus 8, (2), 53-55.

Kari, J. 1980. Tutkimuksen hyödyntäminen opettajien täydennyskoulutuksessa 1980-luvulla. Kasvatus $11,(6), 383-384$.

Lampi, H. 1977. Korkea-asteen täydennyskoulutuksen kehittämisestä. Kasvatus 8, (2), 91-94.

Renko, M. \& Taipale, H. 1973. SIVA-koulutustutkimus I. SIVA-koulutussuunnitelman kuvaus ja opetusteknologinen kritiikki. Jyväskylän yliopisto, Kasvatustieteiden tutkimuslaitoksen julkaisuja 211.

Sysiharju, A-L. \& Kari, J. 1975. Uusi edistysaskel täydennyskoulutuksessa, Suomen opettajankou- luttajien lakisääteisen jatko-opiskelun käynnistyminen syksyllä 1974. Opettaja $70,(20)$, $20-21$.

Sysiharju, A-L. 1976. Erään ammatillisen täydennyskoulutusprosessin pedagogista analyysia esimerkkitapauksena korkeakoulujen opettajankoulutusyksiköiden lehtoreiden lakisääteisen jatko-opiskelun toteutus 1974-76. Jyväskylän yliopisto, Kasvatustieteiden tutkimuslaitoksen selosteita ja tiedotteita 75 .

Opettajien jatkokoulutustoimikunnan mietintö, Komiteanmietintö 1973:51, Helsinki 1973

Täydennyskoulutustoimikunnan I osamietintö. Komiteanmietintö 1975:57, Helsinki 1975

Täydennyskoulutustoimikunnan II osamietintö. Komiteanmietintö 1976:23, Helsinki 1976. 